\title{
Screening of salt tolerant sugarcane endophytic bacteria with potassium and zinc for their solubilizing and antifungal activity
}

\author{
Mahboobeh Pirhadi ${ }^{1}$, Naeimeh Enayatizamir ${ }^{1}$, Hossein Motamedi ${ }^{2}$ and Karim Sorkheh ${ }^{3}$ \\ ${ }^{1}$ Department of Soil Science, Faculty of Agriculture Shahid Chamran University of Ahvaz, Iran \\ ${ }^{2}$ Department of Biology, Shahid Chamran University of Ahvaz \\ ${ }^{3}$ Department of Anatomy and Plant Breeding, Faculty of Agriculture, Shahid Chamran University of Ahvaz, Iran
}

\begin{abstract}
Nowadays high consumption of fertilizers and fungicides in agriculture can increase the problem of soil salinity. Some endobacteria survive in saline condition and induce plant resistance in harm environment. We examined the diversity of halotolerant endophytic bacteria in the internal tissues of sugarcane roots, stems and leaves, with zinc and potassium solubilizing ability and also their antifungal activity. Nutrient Agar medium was used to isolate endophytic bacteria, and then they were screened in view of salinity tolerance on nutrient agar medium containing different concentrations $(100,200,400,600 \mathrm{mM})$ of $\mathrm{NaCl}, \mathrm{CaCl}_{2}$ and $\mathrm{MgCl}_{2}$ at ratio of 3: 2: 1 . Zinc and potassium solubilizing ability of isolates was respectively assessed using PVK medium containing $0.1 \%$ insoluble zinc compound (zinc oxide) and Alexandrov agar medium containing vermiculite. The effect of superior isolates inoculation to supply potassium for wheat was examined in greenhouse condition. As well as antifungal activity of isolates against Fusarium sp. was determined using a dual culture technique. DNA of superior isolates was extracted and the 16S rRNA gene was partially sequenced and used for molecular identification. From 55 endophytic bacteria, 5 halotolerant isolates which solubilize potassium and zinc selected to assay antifungal activity. The isolates were divided into three genus were composed of Enterobacter cloacae, Bacillus pumilus, Pseodomonas sp. Inoculating Enterobacter cloacae (R-1) with higher potassium solubilizing index into pot caused to increase uptake of $\mathrm{K}$ by wheat. Antifungal activity of Pseodomonas sp (S-49) and Enterobacter cloacae (R-10) was higher than other isolates. These results showed that some of isolates are integral part of sugarcane as endophytic bacteria survive in saline environment and have antifungal activity.
\end{abstract}

KEY WORDS: BIOFERTILIZER, INHIBITION, SALINITY, DISSOLUTION

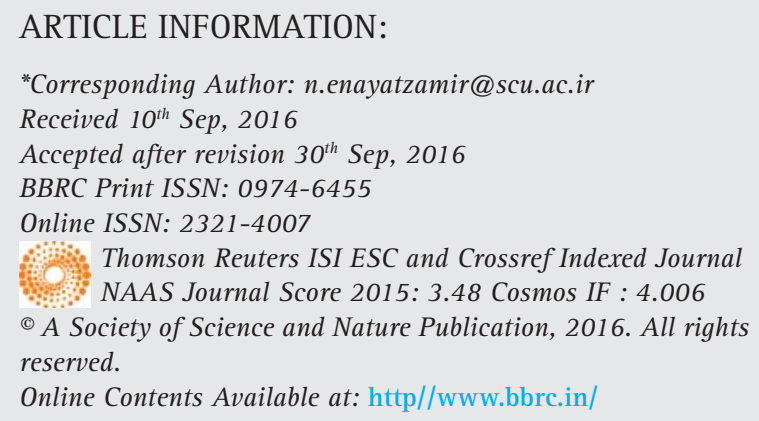


INTRODUCTION

Bacteria that exist within plant tissues during at least one period of their life-cycles without any adverse influences on plant growth called endophyte. These microorganisms set up a mutualistic relationship with the plants, because of ecological advantages to them. Endophytic bacteria provide more benefits than rhizospheric bacteria because: endophytic bacteria living inside of organs and tissues of the plant that keeps safe them from unfavorable environmental conditions than in the rhizosphere; they cannot be washed away by rainfall, runoff or irrigation such as rhizospheric bacteria; they are less exposed to UV radiation and there isn't a lot of competition among them as in the rhizosphere, (Coêlho et al. 2011, Gaiero et al. 2013, Hidayati et al. 2014, Jhala et al. 2015 and Yuan et al. 2015).

Endophytic bacteria have been distributed in many plant species and isolated from different plant organs such as roots, stems, leaves, fruit, flowers and seeds. This microbial community may play an important role in agriculture by contributing plant development through producing phytohormones, siderophores increasing resistance to pathogens, promoting biological nitrogen fixation and antibiotic production, (0'Sullivan and Gara 1992, Pal et al. 2001, Han et al. 2005 Strobel and Daisy 2003 Karthikeyan et al. 2005 and Feng et al. 2006 and El-Deeb et al. 2013).

Sugarcane (Saccharum officinarum L.) is a major crop in Iran, where it is grown for production of sugar, bioethanol, and its waste such as bagasse and vinasse can be used to conserve soil against erosion. Consequently, sustaining and enhancing the growth and yield of sugarcane have become a major focus of research. The growth and performance of sugarcane in the field are adversely affected by a number of abiotic and biotic factors, including soil salinity and a wide range of fungal and bacterial diseases. On the other hand to get sustainable and organic agriculture it is necessary to use soil potential and reduce utilization of chemical fertilizers and pesticides. Potassium is one of the major nutrients, essential for plant growth. Potassium is associated with movement of water, nutrients, and carbohydrates in plant tissue. If potassium is deficient or not supplied in adequate amounts, growth is stunted and yields are reduced, (Ashley et al. 2006).

Most of the potassium in soil exists in various insoluble minerals, (Goldstein 1994). Microorganisms play an important role to release potassium from minerals and supply soluble $\mathrm{K}$ for plant. These bacteria are usually known as potassium solubilizing bacteria or biological potassium biofertilizers. Among the micronutrients, zinc deficiency often happens in crops due to low solubility of zinc in soil, (Iqbal et al. 2010). The solubility of
Zn depends upon soil pH, cationic competition and soil moisture, (Vasanthi et al. 2012). The majority of soils under sugarcane cultivation in the Khuzestan province have more than $40 \%$ of lime and their $\mathrm{pH}$ is greater than 7 , hence are often zinc deficient. Some microorganisms are able to dissolve the zinc-containing compounds and release Zn, (Han and Lee 2006, Sharma et al. 2012 and Diep and Hieu 2013).

Excessive using of pesticides causes environmental problems and adversely affects the health of living organisms and this has prompted researchers to look for new environment friendly solutions for controlling plant pathogens. Recently, many studies have revealed the potential of endophytic bacteria for biological control of fungal diseases, (Munif et al. 2012), (SzilagyiZecchin et al. 2014), (Xu et al. 2007). The antifungal properties of endophytic bacteria are attributed to their ability to produce antibiotics, (Wang et al. 2013) or/and hydrolytic enzymes (Bacon and Hinton 2011).

In sugarcane, most of the research on endophytic bacteria has focused on diazotrophs (Muangthong et al 2015), (Boddey et al. 2003), (Ramos et al. 2011), and to our knowledge there is not any report on investigation of potassium and zinc solubilizing ability of endophytic bacteria from sugarcane. So, the present study aimed to isolate salt tolerance endophytic bacteria from sugarcane with potassium and zinc solubilizing ability and antifungal activity. Understanding the diversity of beneficial endophytic bacteria and their role in plant production has important implication in agriculture to encourage using them as eco-friendly approaches to manage crop production and sustain agro-ecosystem, (Schenk et al., 2012).

\section{MATERIAL AND METHODS}

\section{ISOLATION OF ENDOPHYTIC BACTERIA}

Bacteria were isolated from the tissues of sugar cane grown on the Debal-Khazaei agro-industrial unit located in Ahvaz-Abadan road in the province of Khozestan, Iran (latitude $31^{\circ} 05^{\prime}$; longitude $\left.48^{\circ} 30^{\prime}\right)$. To isolate endophytic bacteria, samples of roots, leaves and stems weighing $10.0 \mathrm{~g}$ were washed in tap water and surface sterilized according to the method of Marcon et al. (2002). The inner section of the stem was removed using a sterilized hole punch. The organs were placed in separate sterile mortar and were well crushed into $90 \mathrm{ml}$ sterile physiologic serum until to obtain a homogeneous suspension and serially diluted with sterile physiologic serum. About $50 \mu \mathrm{l}$ of $10^{3}-10^{8}$ dilutions was inoculated onto nutrient agar medium and incubated at $28^{\circ} \mathrm{C}$ for 72 $\mathrm{h}$. All bacterial colonies were purified according to their morphology on nutrient agar. 


\section{SCREENING OF ENDOPHYTIC BACTERIA FOR CHARACTERISTICS OF SALT TOLERANCE}

To determine salt tolerance of isolates, from the overnight culture of each isolates were dropped in triplicate on nutrient agar plate containing different concentrations (100, 200, 400, $600 \mathrm{mM}$ ) of $\mathrm{NaCl}, \mathrm{CaCl}_{2}$ and $\mathrm{MgCl}_{2}$ mixture at a ratio of 3:2: 1 and incubated at $30^{\circ} \mathrm{C}$ for three days. Growth colony diameter was recorded every day. A control without any salt addition was kept to compare colony growth. Percentage reduction of growth in salt amended media was calculated by using the formula (100 x A-B /A), where A is colony diameter growth in control plate in ' $\mathrm{mm}$ ' of the isolate and B is colony diameter growth in salt amended plate.

\section{POTASSIUM SOLUBILIZATION ASSAY}

Alexandrov culture medium was used to assay the isolates potassium solubilizing ability with following ingredients: $0.5 \%$ glucose, $0.2 \% \mathrm{Ca}_{3}\left(\mathrm{PO}_{4}\right)_{2}, 0.05 \% \mathrm{MgSO}_{4} \cdot 7 \mathrm{H}_{2} \mathrm{O}$, $0.01 \% \mathrm{CaCO}_{3}, 0.0006 \% \mathrm{FeCl}_{2}, 0.15 \% \mathrm{~K}_{2} \mathrm{HPO}_{4}$ or vermicu-


from the overnight culture of isolates were dropped on Alexandrov agar medium and were incubated at $30^{\circ} \mathrm{C}$ for 3 days. Colony diameter was measured at third day. Solubility index was calculated by using the clear zone diameter / colony diameter formula (Shanware et al. 2014).

\section{EFFECT OF SELECTED ISOLATE ON WHEAT PLANT GROWTH}

Based on solubilizing ability, one isolate were selected to test its effect on potassium uptake by wheat. For this, greenhouse experiment consisted of a $2 \times 3$ factorial in complete randomized design whit four replications was arranged. The factors included two levels of inoculation (with and without inoculant) and three levels of potassium. The nitrogen fertilizer used $140 \mathrm{~kg} / \mathrm{ha}$ urea, 90 $\mathrm{mg} / \mathrm{kg} \mathrm{P}$ as single super phosphate before seed sowing to prevent possible effects of nutrient deficiency. Potassium from source of potassium sulfate applied at three levels of $120 \mathrm{mg} / \mathrm{kg}$ (K3), $60 \mathrm{mg} / \mathrm{kg}$ (K2) and without potassium application (K1). The soil was completely mixed and irrigated by distilled water to field capacity (70\%). Seeds were surface sterilized in 10\% sodium hypochlorite solution for $10 \mathrm{~min}$, then rinsed with sterilized distilled water and air dried (Ahmad and Haddad 2011).The seeds were planted in pots containing $4 \mathrm{~kg}$ of steam sterilized clay loam soil. Overnight culture of isolate was diluted to $10^{6} \mathrm{CFUmL}^{-1}$ and then applied under seeds. Potassium concentration of leaves three month after growing was analyzed after dry digestion of organ using flame photometer (Gupta 2004). The data were analyzed statisti- cally via SAS version 9.1. Mean comparisons was done using Duncan test at 5\%.

\section{ZINC SOLUBILIZATION ASSAY}

The isolates were examined for zinc solubilization ability by using modified PVK medium (Pikovskaya 1948). The medium including: $10.0 \mathrm{~g}$ glucose, $1.0 \mathrm{~g}$ ammonium sulphate, $0.2 \mathrm{~g}$ potassium chloride, $0.2 \mathrm{~g}$ dipotassium hydrogen phosphate, $0.1 \mathrm{~g}$ magnesium sulphate, $0.2 \mathrm{~g}$ Yeas, $0.1 \%$ insoluble zinc from source of $\mathrm{ZnO}$ in 1000 $\mathrm{ml}$ distilled water with $\mathrm{pH}$ 7.0. From the overnight culture of isolates $7 \mu$ l were dropped on plates containing the mentioned medium and incubated at $30^{\circ} \mathrm{C}$ for $72 \mathrm{~h}$. Colony and halo zones diameter was recorded. Solubility index was calculated by using the clear zone diameter / colony diameter formula, (Ramesh et al. 2014).

\section{ANTIFUNGAL ACTIVITY ASSAY}

The isolates with salinity tolerance and potassium and zinc solubilization were screened for in vitro antagonism against Fuzarium. sp on PDA plates using a dual culture technique. The controls were prepared using pure cultures of fungi. The plates were incubated at $30^{\circ} \mathrm{C}$ until fungal mycelia covered the agar surface of the control plates. Radial growth of Fuzarium. sp was measured on the 5th days after inoculation. The inhibition percent in the mycelial development of the pathogen fungus was calculated by the formula: $\mathrm{R} 1=(\mathrm{C}-\mathrm{T}) / \mathrm{C} \times 100$; where $\mathrm{RI}$ is the inhibition percentage of the radial mycelial growth, $C$ is the radial growth of the pathogen in the control $(\mathrm{mm})$, and $\mathrm{T}$ is the radial growth of the pathogen in dual culture, (Ohike et al. 2013).

\section{IDENTIFICATION OF ENDOPHYTIC BACTERIA}

The superior isolates from point of characteristics related to plant growth promotion were identified by morphological,physiological and biochemical characteristics with reference to Bergeys Manual of Systematic Bacteriology and by sequencing the 16S rRNA, (Weisburg et al., 1991).

\section{RESULTS AND DISCUSSION}

In total, 55 endophytic bacteria from the root (10 isolates), stem (21 isolates) and leaves ( 24 isolates) of the sugarcane were isolated. The results of isolates response to different level of salt concentration have presented in table 1 . Salt tolerance of microorganisms depends on the range of external salinity over which it is able to sustain these conditions in the cytoplasm [(Yeo 1998). The salinity tolerance of isolates was classified as very resistant (0-25\% growth inhibition), resistant (25-50\% growth inhibition), 





moderate resistant (50-75\% growth inhibition), sensitive (75-100\% growth inhibition) and very sensitive (100\% growth inhibition). Isolates growth decreased by increasing salt concentration in the medium. The results revealed that increasing salt concentration induced some isolates growth and seams they are halophile. Most of isolates classified in moderate group. Microorganisms possess multiple strategies to overcome salinity. One of these strategies is the osmoprotectants accumulation in the cytoplasm, (Mishra and Sharma 2012). This important feature demonstrates the potential of endophytic bacteria to alleviate salt stress of host plant by exopolysaccharides production which restricts sodium adsorption by plant (Milosevic et al. 2012) or indirectly by auxin production, (Yaish et al. 2015).

\section{POTASSIUM SOLUBILIZATION ASSAY}

The dissolution of insoluble potassium base on halo zone around the colonies of the isolates has shown in table 2. Highest solubility index recorded in R-1 isolate (Enterobacter) in presence of both vermiculite and $\mathrm{K}_{2} \mathrm{HPO}_{4}$ followed by S-49 isolate (Pseudomonas).

Most of the potassium solubilizing bacteria obtained from the plant rhizosphere [(Murali et al 2005), (Zhang and Kong 2014)] and identified as Bacillus sp., Pseudomonas sp., Bacillus mucilaginosus [(Liu 2001), (Murali et al. 2005), (Zhou et al. 2006), (Sugumaran and Janarthanam 2007)]. However, there are relatively few studies on potassium solubilizing bacteria in the sugarcane rhizosphere. Ghevariya and Deasi (2014) identified Pseudomonas sp. capable solubilize potassium from mica.
The ability of potassium solubilizing by Enterobacter spp. has been already reported (Zhang and Kong 2014). Yuan et al. (2015) isolated Enterobacter spp. as endophytic bacteria from rhizome, root, leaves and stem of Moso Bamboo with the ability of dissolving potassium.

\section{PLANT GROWTH AND POTASSIUM UPTAKE BY WHEAT}

Inoculation influence on plant growth and potassium concentration has been shown in figure1.The results showed that potassium concentration of leaves of wheat significantly $(\mathrm{P} \leq 0.05)$ increased by inoculation and increased level of potassium application. The least potassium concentration was recorded in un-inoculated plants without potassium application, and the highest observed in inoculated plant and with potassium application (K3) followed by inoculated plant with second level of potassium application (K2) without significant difference between them. From this obtained results, it is clear that bio-fertilizer application were more effective to increase potassium concentration.

Increasing the bioavailability of $\mathrm{P}$ and $\mathrm{K}$ in soils with inoculation of PGPR such as Bacillus mucilaginosus, by producing organic acids and other chemical which may lead to increased $\mathrm{K}$ and $\mathrm{P}$ uptake and plant growth, was reported by many researchers, (Sheng et al. 2002; Lin et al. 2002). Nutrient uptake enhance by inoculated plants may attribute to the production of plant growth regulators by the bacteria at the root interface, which stimulated root development and resulted in better absorption of water and nutrients from the soil, (Abbasi et al. 2011).

\begin{tabular}{|c|c|c|c|c|c|c|c|c|}
\hline \multirow{2}{*}{$\begin{array}{l}\text { Isolate } \\
\text { code }\end{array}$} & \multirow[t]{2}{*}{ sample } & \multirow[t]{2}{*}{ Diameter } & \multicolumn{3}{|c|}{ Vermiculite } & \multicolumn{3}{|c|}{$\mathrm{K}_{2} \mathrm{HPO}_{4}$} \\
\hline & & & $\begin{array}{l}\text { Colony } \\
\text { diameter } \\
(\mathrm{mm})\end{array}$ & $\begin{array}{c}\text { Halo } \\
\text { diameter } \\
(\mathrm{mm})\end{array}$ & $\begin{array}{c}\mathrm{HD} / \mathrm{CD} \\
(\mathrm{mm})\end{array}$ & $\begin{array}{l}\text { Colony } \\
\text { diameter } \\
(\mathrm{mm})\end{array}$ & $\begin{array}{c}\text { Halo } \\
\text { diameter } \\
(\mathrm{mm})\end{array}$ & $\begin{array}{c}\mathrm{HD} / \mathrm{CD} \\
(\mathrm{mm})\end{array}$ \\
\hline $1 \mathrm{~N}-\mathrm{R}-1$ & Root & Enterobacter & 5 & 10 & 2 & 4 & 5 & 1.25 \\
\hline $5 N-R-5$ & Root & Streptococcus & 4 & 1 & 0.25 & 4 & 1 & 0.25 \\
\hline $7 \mathrm{~N}-\mathrm{R}-7$ & Root & Enterobacter & 3.5 & 0.5 & 0.14 & - & - & - \\
\hline $8 N-R-8$ & Root & Streptococcus & 4 & 1 & 0.25 & - & - & - \\
\hline 9N- R-9 & Root & Enterobacter & 4 & 2 & 0.5 & 5 & 5 & 1 \\
\hline $10 N-R-10$ & Root & Enterobacter & 4 & 1 & 0.25 & - & - & - \\
\hline $41 \mathrm{~N}-\mathrm{S}-41$ & Stem & Arthrobacter & 8 & 2 & 0.25 & 8 & 1 & 0.125 \\
\hline $49 N-S-49$ & Stem & Pseudomonas & 6 & 10 & 1.6 & 6 & 4 & 0.66 \\
\hline $51 \mathrm{~N}-\mathrm{B}-51$ & Leaf & Arthrobacter & 5 & 3 & 0.6 & 8 & 2.5 & 0.31 \\
\hline $52 N-B-52$ & Leaf & Enterobacter & 5 & 4 & 0.8 & 10 & 2 & 0.2 \\
\hline $56 N-B-56$ & Leaf & Bacillus & - & - & - & - & - & - \\
\hline
\end{tabular}



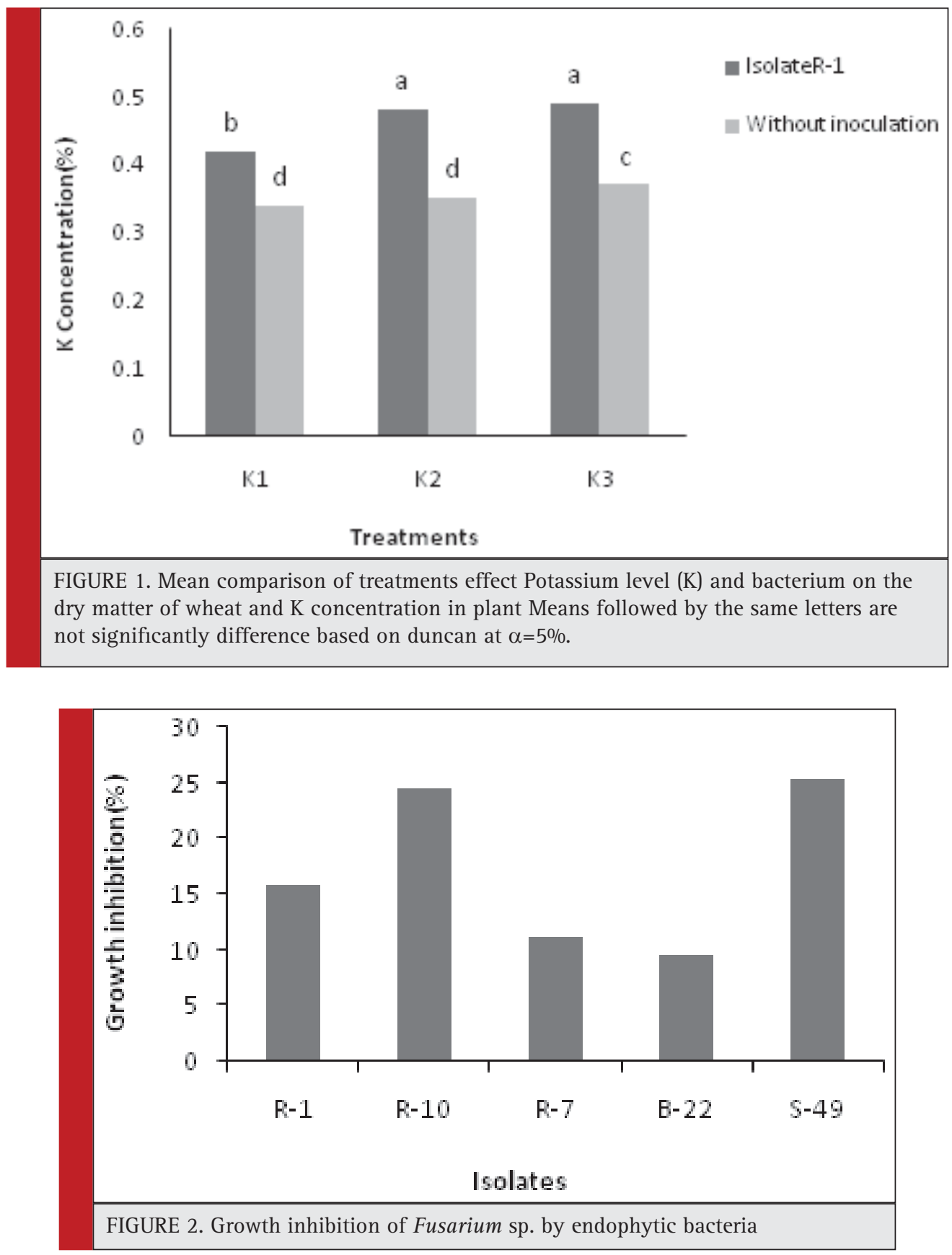

\section{ZN SOLUBILIZATION ASSAY}

The bacteria were able to dissolve zinc in plates produced clear halo around them (Table 3). Five isolates had the ability of zinc oxide dissolution. Isolates R-7 and R-10 had the highest rate of zinc dissolution among the five zinc solubilizing bacteria. Both of the bacteria were isolated from the roots of sugarcane and are belonging to the genus Enterobacter. Zinc solubilizing bacteria have been isolated from different plant rhizhosphere. Enterobacter aerogenes and Pseudomonas aerugi-

\begin{tabular}{|c|c|c|c|}
\hline $\begin{array}{l}\text { Isolate } \\
\text { code }\end{array}$ & $\begin{array}{c}\text { Colony } \\
\text { diameter }(\mathrm{mm})\end{array}$ & $\begin{array}{c}\text { Halo zone } \\
\text { diameter }(\mathrm{mm})\end{array}$ & $\begin{array}{l}\mathrm{HD} / \mathrm{CD} \\
(\mathrm{mm})\end{array}$ \\
\hline $1 \mathrm{~N}-\mathrm{R}-1$ & 7 & 7 & 1 \\
\hline 7N- R-7 & 5.5 & 6.5 & 1.18 \\
\hline $10 \mathrm{~N}-\mathrm{R}-10$ & 5 & 7 & 1.4 \\
\hline $22 \mathrm{~N}-\mathrm{B}-22$ & 3 & 3 & 1 \\
\hline $49 N-S-49$ & 4 & 4 & 1 \\
\hline
\end{tabular}


nosa from agricultural fields (Sunithakumari et al. 2016), Bacillus sp. from sugarcane (Vasanthi et al. 2012) and Pseudomonas sp. and Bacillus sp. from soybean rhizosphere (Sharma et al. 2012) have been reported to solubilize insoluble zinc. Of the basic mechanisms for the dissolution of zinc-containing compounds is the secretion of organic acids which reduce the $\mathrm{pH}$ and thereby increase the availability of zinc (Sunithakumari et al. 2016).

The biochemical information and molecular identification of isolates showed R-1, R-7, R-10 isolates are belonging to Enterobacter cloacae under accession number of KX262849, KX262850 and KX262851 respectively and B-22 and S-49 isolates were Bacillus pumilus (KX262852) and Pseudomonas sp. (KX262853) respectively. Enterobacter isolate has the ability to withstand different abiotic stresses such as salinity (Tantawy et al. 2009) and increased the resistance, growth and nitrogen fixing of inoculated plant under salt stress (Tantawy et al. 2009).

\section{IN VITRO ANTAGONISTIC ACTIVITY OF ISOLATES}

Results showed that each isolate could prevent Fusarium growth but there was difference among them. Highest growth inhibition was recorded by applying S-49 isolate which followed by R-10 isolate (Figure 1). Three other isolates ability to inhibit Fusarium growth in dual culture was less than mentioned two isolates which proves their efficacy in management of crop diseases. However, it is necessary to do complementary experiment to confirm their antagonistic ability and also their mechanisms to inhibit pathogens growth.It has been reported antagonistic activity of Pseudomonas aeruginosa, P. fluorescens and P. putida isolated from the stalks of sugarcane against Colletotrichum falcatum (Viswanathan et al. 2003), Bacillus amyloliquefaciens, B. subtilis, and B. thuringiensis from banana against Fusarium oxysporum f. sp cubense and Colletotrichum guaranicola, (Souza et al. 2014).

Most bacterial species with biological control potential isolated from the soil rhizosphere, but their use is limited because they can hardly colonize plant roots, perhaps endophytic bacteria can be good choice for this purpose (Chang-Qing, Zhao et al. 2008). The biocontrol potential of enophytic bacteria against Verticilium dahlia has been reported by Ferrara et al. (2012). Plant growth promoting endobacteria may induce the plant's defense system against pathogens or enhance plant resistance through production of antimicrobial compounds (Heydari and Pessarakli, 2010). The growth inhibition of pathogen may be related to antibiotic and toxin secretion (Wang et al. 2013), compete with patho- gens for space and nutrients impoverishment and $\mathrm{pH}$ alteration in the medium (Backman and Sikora 2008) or cell wall degrading enzymes secretion such as chitinase and $\beta$-1, 3-glucanase (Roberts and Selitrennikoff 1988).

\section{CONCLUSION}

Salinity is one of the most widespread constraints to soil fertility. During the latest years, a great attention has been paid to saline soils due to the reducing arable land, and of the increasing demand for agricultural production of areas influenced by secondary salinisation processes. Our study revealed a high plasticity of bacterial phyla that evidently possess genera and species adaptable to salinity conditions with plant growth promoting properties.There is scope for use of zinc and potassium solublizing bacteria as potential biofertilizers for reclamation saline soils of local area because isolates belongs to the same soil. From 59 isolates, five isolate having plant growth promotion (potassium and zinc solubilizing ability) identified. We also showed that Pseudomonas $s p$. and Enterobacter cloacae have the ability to inhibit the growth of Fusarium. It is interesting to investigate which mechanisms would be related to fungal inhibition activity of strains in our study. Our experiment demonstrated the advantage of isolate R-1 (Enterobacter cloacae) inoculation on potassium uptake by wheat. High cost of chemical fertilizers and harmful environmental effects of them caused to recommend using of biological fertilizer to increase soil fertility. Future studies are promising to test the biotechnological potential of these strains under field conditions in the hope that they will contribute as an alternative source of biological fertilizer and biological control.

\section{ACKNOWLEDGMENTS}

We thank Shahid Chamran University of Ahvaz for academic support and Iran National Science Foundation for financial support under grant number of 93045179.

\section{REFERENCES}

Abbasi M., Sharif S., Kazmi M., Sultan T., Aslam M. (2011). Isolation of plant growth promoting rhizobacteria from wheat rhizosphere and their effect on improving growth, yield and nutrient uptake of plants. Plant Biosystems, 145(1): 159-168.

Aleksandrov V., Blagodyr R., Ilev I. (1967). Liberation of phosphoric acid from apatite by silicate bacteria. Mikrobiol Z (Kiev), 29:111-114.

Araújo W.L., Marcon J., Maccheroni W., Elsas J.D., Vuurde J.W., Azevedo J.L. (2002). Diversity of endophytic bacterial populations and their interaction with Xylella fastidiosa in citrus plants. Appl. Environ. Microbiol. 68(10): 4906-4914. 
Ashley M .K., Grant M., Grabov A. (2006). Plant responses to potassium deficiencies: a role for potassium transport proteins. J. Exp. Bot. 57(2): 425-436.

Bacon C.W., Hinton D.M. (2011). Bacillus mojavensis: its endophytic nature, the surfactins, and their role in the plant response to infection by Fusarium verticillioides. In Bacteria in Agrobiology: Plant Growth Responses. pp. 21-39.

Backman PA and Sikora RA (2008) Endophytes: An emerging tool for biological control Biol.Control. 46: 1-3

Boddey R. M., Urquiaga S., Alves B. J. R., Reis V. (2003). Endophytic nitrogen fixation in sugarcane: present knowledge and future applications. Plant Soil. 252: 139-149.

Chang-Qing ZS-MS., Zhao WY-XLJ., Xian-Cheng X-YZ. (2008). Isolation and Characterization of Antifungal Endophytic Bacteria from Soybean. Microbiology, 10, 27.

Coêlho M.M., Ferreira-Nozawa M.S., Nozawa S.R., Santos A.L. (2011). Isolation of endophytic bacteria from arboreal species of the Amazon and identification by sequencing of the $16 \mathrm{~S}$ rRNA encoding gene. Genet Mol Biol. 34(4): 676-680.

de Santi Ferrara F. I., Machado Oliveira Z., Soto Gonzales H. H., Segal Floh E. I., Ramos Barbosa H. (2002). Endophytic and rhizospheric enterobacteria isolated from sugar cane have different potentials for producing plant growth-promoting substances. Plant Soil. 353: 409-417.

Diep C.N., Hieu T.N. (2013). Phosphate and potassium solubilizing bacteria from weathered materials of denatured rock mountain, Ha Tien, Kiên Giang province Vietnam. Am. J. Life Sci. 1(3): 88-92.

El-Deeb B., Fayez K., Gherbawy Y. (2013). Isolation and characterization of endophytic bacteria from Plectranthus tenuiflorus medicinal plant in Saudi Arabia desert and their antimicrobial activities. J. Plant Interact. 8(1): 56-64.

Feng Y., Shen D., Song W. (2006). Rice endophyte Pantoea agglomerans YS19 promotes host plant growth and affects allocations of host photosynthates. J. Appl. Microbiol. 100(5): 938-945.

Ghevariya K.K., Desai P.B. (2014). Rhizobacteria of sugarcane: In vitro screening for their plant growth promoting potentials. Res. J. Rec. Sci. 3: 52-58.

Gaiero J.R., McCall C.A., Thompson K.A., Day N.J., Best A.S., Dunfield K.E.( 2013). Inside the root microbiome: bacterial root endophytes and plant growth promotion. Am. J. Bot. 100(9): 1738-1750.

Goldstein AH (1994) Involvement of quino protein glucose dehydrogenase in the solubilization of exogenous mineral by Gram negative bacteria In: Torriani Gorini A., A Yagli, E Silver S Eds Phosphates in Microorganisms: Cellular and Molecular Biology ASM Press Washington DC 194-203.

Gupta P.K. (2004). Soil, Plant, Water And Fertilizer Analysis. (Agrobios (India).

Han H-S., Lee K. (2006): Effect of co-inoculation with phosphate and potassium solubilizing bacteria on mineral uptake and growth of pepper and cucumber. Plant Soil Environ. 52(3): 130-136.
Han J., Sun L., Dong X., Cai Z., Sun X., Yang H., Wang Y., Song W. (2005).Characterization of a novel plant growth-promoting bacteria strain Delftia tsuruhatensis HR4 both as a diazotroph and a potential biocontrol agent against various plant pathogens. Syst Appl Microbiol 28(1): 66-76.

Heydari A., Pessarakli M. (2010). A review on biological control of fungal plant pathogens using microbial antagonists. J. Biol. Sci. 10: 273-290.

Hidayati U., Chaniago I.A., Munif A., Santosa D.A. (2014). Potency of Plant Growth Promoting Endophytic Bacteria from Rubber Plants (Hevea brasiliensis Müll. Arg.). J. Agron. 13(3): 147-152.

Iqbal U., Jamil N., Ali I., Hasnain S. (2010). Effect of zincphosphate-solubilizing bacterial isolates on growth of Vigna radiata. Annal Microbiol 60(2): 243-248.

Jhala Y., Shelat H., Vyas R., Panpatte D. (2015). Biodiversity of Endorhizospheric Plant Growth Promoting Bacteria. J. Biofertil. Biopestic. 6(1): 1-5.

Karthikeyan M., Bhaskaran R., Radhika K., Mathiyazhagan S., Jayakumar V., Sandosskumar R., Velazhahan R. (2005). Endophytic Pseudomonas fluorescens Endo2 and Endo35 induce resistance in black gram (Vigna mungo L. Hepper) to the pathogen Macrophomina phaseolina. J. Plant Interact. 1(3): 135-143.

Lin Q.M., Rao Z. H., Sun Y X., Yao J., Xing L.J. (2002). Identification and practical application of silicate dissolving bacteria. Agr. Sci. China. 1: 81-85.

Liu G. (2001): Screening of silicate bacteria with potassium releasing and antagonistical activity. Chin. J. Appl. Environ. Biol. 7 (1): 66-68.

Milosevic N., Marinkovic J B., Tintor B. (2012). Mitigating abiotic stress in crop plants by microorganisms, Proc. Nat. Sci. Matica Srpska Novi. Sad. 123: 17-26.

Mishra I.G., Sharma A. (2012): Exogenously supplied osmoprotectants confer enhanced salinity tolerance in rhizobacteria. J. Ecobiotechnol. 4: 11-13.

Muangthong A., Youpensuk S., Rerkasem B. (2015). Isolation and characterisation of endophytic nitrogen fixing bacteria in sugarcane. Trop Life Sci Res, 26(1): 41-51.

Munif A., Hallmann J., Sikora R. (2012). Isolation of endophytic bacteria from tomato and their biocontrol activities against fungal disease. Microbiol. Indones. 6(4); 148-156.

Murali G., Gupta A., Nair R.V. (2005). Variations in hosting beneficial plant associated microorganisms by root (wilt) diseased and field tolerant coconut palms of west coast tall variety. Current Sci. 89: 1922-1927.

Ohike T., Makuni K., Okanami M., Ano T. (2013). Screening of endophytic bacteria against fungal plant pathogens. J. Environ. Sci. 25: 122-126.

O'Sullivan DJO., Gara F. (1992): Traits of fluorescent Pseudomonas sp. involved in suppression of plant root pathogens. Microbiol. Rev. 56: 662-676.

Pal K., Tilak K., Saxcna A., Dey R., Singh C. (2001). Suppression of maize root diseases caused by Macrophomina phaseolina, Fusarium moniliforme and Fusarium graminearum by 
plant growth promoting rhizobacteria. Microbiol. Res. 156(3): 209-223.

Pikovskaya R. (1948): Mobilization of phosphorus in soil in connection with vital activity of some microbial species. Mikrobiologiya. 17: 362-370.

Ramesh A., Sharma S.K., Sharma M.P., Yadav N., Joshi O.P. (2014). Inoculation of zinc solubilizing Bacillus aryabhattai strains for improved growth, mobilization and biofortification of zinc in soybean and wheat cultivated in Vertisols of central India. Appl. Soil Ecol. 73, 87- 96.

Ramos P. L., Van Trappen S, Thompson F.L., Rocha R. C. S., Barbosa H. R., De Vos P., Moreira-Filho C. A. (2011). Screening for endophytic nitrogen-fixing bacteria in Brazilian sugar cane varieties used in organic farming and description of Stenotrophomonas pavanii sp. nov. Int. J. Syst. Evol. Microbiol. 61, 926-931.

Roberts W.K., Selitrennikoff C.P. (1988). Plant and bacterial chitinases differ in antifungal activity. Microbiology. 134(1): 169-176.

Schenk P.M., Carvalhais L.C., Kazan K. (2012). Unraveling plant-microbe interactions: can multi-species transcriptomics help? Trends Biotechnol. 30: 177-184.

Shanware A.S., Kalkar S.A. Trivedi M.M. (2014). Potassium Solublisers: Occurrence, Mechanism and Their Role as Competent Biofertilizers. Int. J. Curr. Microbiol. App. Sci. 3: 622-629.

Sharma S.K., Sharma M.P., Ramesh A., Joshi O.P. (2012). Characterization of zinc-solubilizing Bacillus isolates and their potential to influence zinc assimilation in soybean seeds. J. Microbiol. Biotechnol. 22: 352-359.

Sheng X.F., He L.Y., Huang W.Y. (2002). The conditions of releasing potassium by a silicate-dissolving bacterial strain NBT. Agr. Sci. China, 1: 662-666.

Souza A., Cruz J., Sousa N., Procópio A., Silva G. (2014): Endophytic bacteria from banana cultivars and their antifungal activity. Genet. Mol. Res. 13: 8661-8670.

Strobel G., Daisy B. (2003). Bioprospecting for microbial endophytes and their natural products. Microbiol. Mol. Biol. Rev. 67(4): 491-502.

Sugumaran P., Janarthanam B. (2007). Solubilization of potassium containing minerals by bacteria and their effect on plant growth. World J. Agric. Sci. 3(3): 350-355.

Sunithakumari K., Padma Devi S., Vasandha S. (2016) Zinc solubilizing bacterial isolates from the agricultural fields of Coimbatore, Tamil Nadu, India. Curr. Sci.110(2): 196-205.
Szilagyi-Zecchin V.J., Ikeda A.C., Hungria M., Adamoski D., Kava-Cordeiro V., Glienke C., Galli-Terasawa L.V. (2014). Identification and characterization of endophytic bacteria from corn (Zea mays L.) roots with biotechnological potential in agriculture. AMB. Express 4(1): 1-9.

Tantawy A., Abdel-Mawgoud A., El-Nemr M., Chamoun Y.G. (2009). Alleviation of salinity effects on tomato plants by application of amino acids and growth regulators. Eur. J. Sci. Res. 30(3): 484-494.

Vasanthi N., Saleena L. M., Raj S.A. (2012). Concurrent Release of Secondary and Micronutrient by a Bacillus sp. Am. Eurasian J. Agric. Environ. Sci. 12 (8): 1061-1064.

Viswanathan R., Sundar A.R., Premkumari S.M. (2003). Mycolytic effect of extracellular enzymes of antagonistic microbes to Colletotrichum falcatum, red rot pathogen of sugarcane. World J. Microbiol. Biotechnol. 19(9): 953-959.

Wang S., Wang W., Jin Z., Du B., Ding Y., Ni T., Jiao F. (2013). Screening and diversity of plant growth promoting endophytic bacteria from peanut. Afr. J. Microbiol. Res. 7(10): 875-884.

Weisburg W.G., Barns S.M., Pelletier D.A., Lane D.J. (1991). $16 \mathrm{~S}$ ribosomal DNA amplification for phylogenetic study. J. Bacteriol.173(2): 697-703.

Xu D., Xia X., Xu N., An L. (20070. Isolation and identification of a novel endophytic bacterial strain with antifungal activity from wild blueberryVaccinium uliginosum. Ann. Microbiol.57(4): 673-676.

Yaish M.W., Antony I., Glick B.R. (2015). Isolation and characterization of endophytic plant growth-promoting bacteria from date palm tree (Phoenix dactylifera L.) and their potential role in salinity tolerance. Antonie van Leeuwenhoek, 107(6): 1519-1532.

Yeo A. (1998): Molecular biology of salt tolerance in the context of whole-plant physiology. J. Exp. Bot. 49(323): 915-929.

Yuan Z-S., Liu F., Zhang G-F. (2015). Isolation of culturable endophytic bacteria from moso bamboo (Phyllostachys edulis) and 16S rDNA diversity analysis. Arch. Biol. Sci. 67(3): 10011008.

Zhang C., Kong F. (2014). Isolation and identification of potassium-solubilizing bacteria from tobacco rhizospheric soil and their effect on tobacco plants. Appl. Soil Ecol. 82, 18-25.

Zhou H., Zeng X., Liu F., Qiu G., Hu Y. (2006). Screening, identification and desilication of a silicate bacterium. J. Cent. South Univ. Technol. 13: 337-341. 